\title{
Розробка та валідація моделі BBEP-1000 для коду PARCS
}

\section{- Кухоцька Оксана Василівна}

Державне підприємство «Державний науково-технічний центр

з ядерної та радіаційної безпеки», м. Київ, Україна

ORCID: https://orcid.org/0000-0001-5551-8622

- Овдієнко Юрій Миколайович, канд. техн. наук

Державне підприємство «Державний науково-технічний центр

з ядерної та радіаційної безпеки», м. Київ, Україна

ORCID: https://orcid.org/0000-0002-7016-1841

\section{- Єременко Максим Леонідович}

Державне підприємство «Державний науково-технічний центр

з ядерної та радіаційної безпеки», м. Київ, Україна

ORCID: https://orcid.org/0000-0002-5411-7920

Сучасні підходи до моделювання процесів в активній зоні, насамперед у перехідних та аварійних режимах, 3 метою проведення аналізу безпеки ядерних реакторів, вимагають використання сполучених теплогідравлічних та нейтронно-фізичних розрахункових програм. Однією з таких програм $\epsilon$ комп'ютерний код TRACE з модулем тривимірної кінетики PARCS.

Розробка розрахункової моделі водо-водяного енергетичного реактора (BBEP-1000) для коду PARCS та подальша їі валідація $\epsilon$ складною багатоступеневою задачею, починаючи з підготовки бібліотеки нейтронно-фізичних констант, від якості якої залежить точність моделювання фізичних процесів в активній зоні, та закінчуючи проведенням валідаційних розрахунків та їх аналізом.

У цій статті стисло описано всі стадії розробки розрахункової моделі та результати валідаційних розрахунків - наведено підходи до підготовки бібліотеки нейтронно-фізичних констант, необхідної для розрахунків кодом PARCS, коротко описані розроблені нейтронно-фізична та теплогідравлічна моделі активної зони та наведені результати валідаційних розрахунків реалізованої моделі BBEP-1000 для коду PARCS.

Метою проведених розрахунків $\epsilon$ валідація розробленої розрахункової моделі активної зони ВBEP-1000 для комп'ютерного коду PARCS, а саме підтвердження того, що розроблена модель придатна для застосування у рамках проведення нейтронно-фізичних розрахунків стаціонарних станів та перехідних і аварійних режимів експлуатації реакторної установки ВВЕР-1000. Валідація розрахункової моделі полягала в порівняльному аналізі отриманих результатів розрахунку основних нейтронно-фізичних характеристик із результатами, отриманими під час експериментальних досліджень чотирьох реальних паливних завантажень енергоблока № 2 Відокремленого підрозділу «Хмельницька атомна електростанція», та з отриманими результатами розрахунку з використанням коду DYN3D для аналогічних розрахункових станів. Розрахункові моделювання охоплювали стани на мінімально контрольованому рівні та номінальному рівні потужності, а також за різних положень робочої групи органів регулювання системи управління і захисту, а також перехідний (динамічний) процес зі спрацюванням прискореного розвантаження блока для третього паливного завантаження енергоблока № 2 Відокремленого підрозділу «Хмельницька атомна електростанція».

Ключові слова: HELIOS, PARCS, валідація моделі, ВВEР, малогрупові константи, НФХ, розрахункова модель.

(с) Кухоцька О. В., Овдієнко Ю. М., Єременко М. Л., 2021

Задля підвищення якості виконання технічної оцінки обгрунтувань безпеки українських атомних електростанцій (АЕС) використовують методологію виконання тривимірних розрахункових аналізів із застосуванням комп'ютерного коду TRACЕ з модулем тривимірної кінетики PARCS [1]. Впровадження такого потужного сполученого нейтронно-фізичного/ теплогідравлічного інструменту спрямовано на підвищення якості виконання Державним 
підприємством «Державний науково-технічний центр з ядерної та радіаційної безпеки» (ДНТЦЯРБ) державної експертизи матеріалів з обгрунтувань безпеки українських АEC, обгрунтувань впровадження нових типів палива та дозволить суттєво розширити можливості ДНТЦ ЯРБ у сфері аналізу безпеки AEC в перехідних режимах, що супроводжуються просторовими деформаціями поля енерговиділення. Втім, постає питання розробки коректної розрахункової моделі для коду PARCS та її безпосередньої валідації.

Це дослідження проведено в рамках Завдання № 4 Угоди № 358160 між Брукхейвенською Національною Лабораторією та ДНТЦ ЯРБ [2].

Для розв'язання задачі транспорту потоку нейтронів в об'ємі активної зони (Ак3) реактора в програмі PARCS використовується двогрупове дифузійне наближення. Для вирішення системи дифузійних рівнянь застосовується нодальний метод. Суть його полягає в тому, що щільність потоку нейтронів в об'ємі розрахункової ноди апроксимується у вигляді розкладання в ряд за системою відомих функцій. Коефіцієнти розкладання знаходяться за умови зшивання струмів і щільності потоків нейтронів на межах нод. Порівняно зі звичайним кінцево-різницевим методом, цей метод дозволяє більш точно врахувати перетікання нейтронів між нодами, що зі свого боку підвищує точність розрахунку щільності потоку нейтронів в об'ємі АкЗ реактора i, отже, енерговиділення. Для нестаціонарного випадку рівняння дифузії розв'язуються залежно від часу, включно з рівнянням для шести груп запізнілих нейтронів:

$$
\begin{aligned}
& \frac{1}{v_{1}^{n}} \frac{\partial \phi_{1}^{n}(\vec{r}, t)}{\partial t}+\nabla \vec{\jmath}_{1}^{n}(\vec{r}, t)+ \\
& +\Sigma_{r}^{n}(\vec{r}, t) \cdot \phi_{1}^{n}(\vec{r}, t)= \\
& =\frac{1}{k_{\text {eff }}^{0}} \sum_{g^{\prime}=1}^{2}\left(1-\beta_{g^{\prime}=1}^{n}\right) \nu \Sigma_{f, g^{\prime}}^{n}(\vec{r}, t) \cdot \phi_{g^{\prime}}^{n}(\vec{r}, t)+ \\
& +\sum_{J=1}^{M} \lambda_{j} C_{j} n_{j}(\vec{r}, t) \\
& \frac{1}{v_{2}^{n}} \frac{\partial \phi_{2}^{n}(\vec{r}, t)}{\partial t}+\nabla \vec{\jmath}_{2}^{n}(\vec{r}, t)+ \\
& +\Sigma_{a}^{n}(\vec{r}, t) \cdot \phi_{2}^{n}(\vec{r}, t)=\Sigma_{S}^{n}(\vec{r}, t) \cdot \phi_{1}^{n}(\vec{r}, t) \\
& \frac{\partial C_{j}^{n}(\vec{r}, t)}{\partial t}=\frac{1}{k_{\text {eff }}^{0}} \sum_{g^{\prime}=1}^{2} \beta_{g^{\prime}, J}^{n} \nu \Sigma_{f, g^{\prime}}^{n}(\vec{r}, t) \times \\
& \times \phi_{g^{\prime}}^{n}(\vec{r}, t)-\lambda{ }_{j}^{n} C_{j}^{n}(\vec{r}, t),
\end{aligned}
$$

$$
\begin{aligned}
& \text { де J=1, M=6; } \\
& \qquad \beta_{g}^{n}=\sum_{J=1}^{M} \beta_{g, J}^{n}-\text { ефективна частка нейтро- }
\end{aligned}
$$

нів, що спізнюються;

$v_{g}^{n}$ - середні швидкості нейтронів в групі g;

$C{ }_{j}^{n}(\vec{r}, t)$ - концентрація ядер-попередників нейтронів, що спізнюються;

$\beta_{g, J}^{n}$ - ефективна частка нейтронів, що спізнюються, групи ј, спричинених діленням нейтронів у групі g;

$\lambda J$ - постійна розпаду попередників нейтронів, що спізнюються, групи ј;

М - кількість груп нейтронів, що спізнюються;

$k_{\text {eff }}^{0}-$ ефективний коефіцієнт розмноження нейтронів у стаціонарному стані.

Розрахунок вищезазначеної системи рівнянь вимагає попередньої підготовки великого обсягу макроскопічних перерізів взаємодії (МПВ) для кожної розрахункової ноди, що формуються в бібліотеку нейтронно-фізичних констант (НФК).

Процес підготовки бібліотеки НФК, від якості якої залежить точність моделювання фізичних процесів в Ак3, є важливим етапом впровадження розрахункового комплексу TRACE/PARCS у практику досліджень безпеки на підставі розв'язання рівняння переносу нейтронів у малогруповому дифузійному наближенні. Необхідна бібліотека HФК для розрахунків PARCS підготовлена в рамках виконання роботи [3] з використанням спектрального коду HELIOS, який, відповідно, моделює геометрію та інші особливості тепловидільної збірки (ТВ3) ВВЕР-1000, та у форматі, передбаченому в коді PARCS.

Після підготовки бібліотеки НФК, розроблено модель для коду PARCS для Ак3 BBEP-1000. Під час розробки розрахункової моделі PARCS використано досвід розробки аналогічних моделей для коду DYN3D, які успішно валідовані. Для аналізу коректності розробленої моделі проведено порівняння результатів розрахунку основних нейтронно-фізичних характеристик (НФХ) Ак3 із результатами, отриманими 3 використанням коду DYN3D для аналогічних розрахункових станів.

Наступним етапом валідації було проведення розрахунків для станів на мінімально контрольованому рівні (МКР) та номінальному рівні потужності, а також за різних положень робочої групи органів регулювання (ОР) системи управління і захисту (СУЗ) для чотирьох реальних паливних завантажень енергоблока № 2 Відокремленого підрозділу «Хмельницька атомна електростанція» (ВП ХАЕС) [4], а також динамічного процесу зі спрацюванням прискореного розвантаження блока (ПРБ) для третього паливного завантаження. 


\section{1 Підготовка бібліотеки НФК}

Під час проведення малогрупових нейтроннофізичних розрахунків (НФР) різних станів реактора дуже важливу роль відіграє питання підготовки малогрупової бібліотеки нейтронно-фізичних перерізів (МГБ НФП), яка містить інформацію про малогрупові НФК, що використовуються В малогрупових дифузійних розрахунках стаціонарних станів та перехідних режимів реактора, адже якість підготовки МГБ НФП визначає в подальшому точність результатів НФР.

Для підготовки МГБ НФК для програми PARCS з фізичного розрахунку ВВЕР розроблено розрахункову модель до спектральної програми HELIOS для паливних касет типу TB3A реактора ВВEР-1000, включно з моделями касет із зануреними ОР СУЗ. Моделі HELIOS розроблені за умов необхідності виведення розрахункової інформації у форматі PMAXS, що забезпечує коректну роботу програми PARCS [3]. Формат PMAXS передбачає внесення в бібліотеку, крім референсних значень МПВ, також їх часткових похідних за трьома групами незалежних змінних:

змінні для поточної ноди - теплофізичні параметри ноди;

змінні для сусідньої ноди - різниця у вигорянні та густині теплоносія між поточною та сусідньою нодами;

фактор наявності поглинача.

Похідні МПВ за незалежними змінними бралися в середній точці між референсним значенням та значенням стану в поточній ноді інтерполяцією згрупованих даних. Внесок незалежних змінних при тому визначається як добуток часткової похідної перерізу взаємодії та величини варіації самої незалежної змінної. Кожна з трьох груп незалежних змінних МПВ (фактор наявності поглинача, змінні для поточної та сусідньої нод) визначається різними способами, що вимагають вибору відповідного набору незалежних змінних для конкретної поставленої задачі.

Формат PMAXS дозволяє ввести в бібліотеку 12 незалежних змінних: фактор наявності поглинача; густину теплоносія та сповільнювача; концентрацію рідкого поглинача в теплоносії та сповільнювачі; температуру палива, теплоносія та сповільнювача; домішки в теплоносії та сповільнювачі; різницю в густині між сусідньою та поточною касетами та різницю у вигорянні між сусідньою та поточною касетами. Враховуючи специфіку реакторів ВВЕР, що $\epsilon$ водоохолоджуваним реактором з водою під тиском, та наявний досвід підготовки бібліотеки МПВ для програми DYN3D [5], у бібліотеку для програми PARCS введено залежність МПВ від таких незалежних змінних: наявність поглинача, густина теплоносія, концентрація борної кислоти в теплоносії, температура палива і теплоносія.

МПВ у форматі PMAXS, що використовуються програмою PARCS, задаються в припущенні врахування загального відхилення від перерізів референсного стану через зміну всіх теплогідравлічних параметрів на основі лінійної суперпозиції змін за окремим параметром, що визначаються з використанням часткових похідних перерізів та урахуванням наявності поглинача. Підходи до вибору параметрів станів Ак3 та методологію підготовки констант у форматі програми PARCS наведено в дослідженні [6].

Крім МПВ, бібліотека була доповнена факторами розривності (assembly discontinuity factors) для всіх типів паливних касет та чарунок відбивача. Застосування факторів розривності реалізовано в розрахунковій моделі PARCS та дозволяє підвищити точність розрахунку розподілу щільності потоку нейтронів в об'ємі АкЗ.

\section{2 Нейтронно-фізична частина розробленої розрахункової моделі АкЗ ВВЕР-1000 для розрахункового коду PARCS}

Код PARCS [1] має гнучкі можливості для формування моделі Ак3 ВВЕР-1000. Вона моделюється у вигляді гексагональних призм, що мають розміри, характерні для кроку розміщення ТВ3 в Ак3 (23,6 см). Висота призм дорівнює висоті паливної частини ТВ3 (355 см). У плані Ак3 на одну ТВ3 передбачено одну розрахункову точку. На підставі виконаного аналізу чутливості та, зважаючи на оптимальне співвідношення точність/витрати розрахункового часу, кількість розрахункових точок в аксіальному напрямку для АкЗ ВВЕР-1000 обрано рівною 20. У цьому разі висота ноди (17,75 см) така, що коли ОР СУЗ займає проміжне положення, використання геометричного зважування $є$ достатнім для отримання гомогенних констант ноди. Висота чарунки аксіального відбивача становить 30 см [7].

Блок нейтронної кінетики PARCS застосовується в інтерфейсі із теплогідравлічним системним кодом TRACE для аналізу аварійних режимів. Оскільки більшість аварійних процесів із введенням позитивної реактивності у ВВЕР-1000 характеризується несиметричною зміною енерговиділення в Ак3, то для їх дослідження в рамках цієї статті розроблено повномасштабну модель Ак3 (360 - симетрія).

Ак3 складається зі 163 паливних касет. Для точного опису процесу витоку нейтронів за межі Ак3 у розроблену модель введено додатковий периферійний ряд із 48 чарунок відбивача. Механічна система ОР складається з 61 пучка поглинаючих елементів із 18 поглинаючих стрижнів СУЗ у кожному. Механічна система 
складається з 10 груп ОР. Загалом у кожній групі по 6 ОР. Винятками є: група 1 - 3 ОР, група 8 - 9 ОР та група 9 - 7 ОР. Розташування груп у моделі Ак3 наведено нижче (Рисунок 1) та характерне для більшості Ак3 ВВЕР-1000 українських АЕС. Для управління реактором у нормальних умовах експлуатації призначено три керуючі групи ОР СУЗ $(10,9$ і 8). Решта - для аварійного та попереджувального захисту (АЗ та ПЗ). Група 10 (робоча) постійно перебуває в Ак3, групи 9 і 8 занурюються в Ак3 під час розвантаження реактора та під час стабілізації ксенонових коливань.

У разі тривалої (більше 12 годин) роботи реактора в стаціонарному стані групи 8 і 9 вилучаються з Ак3; група 10 перебуває в допустимих межах, нижня межа яких залежить від рівня потужності реактора, а верхня - 95 \% від висоти Ак3. Для під- тримки оптимальної форми висотного розподілу енерговиділення і зниження нерівномірності вигоряння палива групу 10 утримували в діапазоні 70 - 90 \% від висоти Ак3.

Для аналізу динамічних процесів у моделі використано шість груп нейтронів, що спізнюються. Наведені в [8] теоретичні та експериментальні дослідження вказують на те, що дані щодо спаду швидкості генерації нейтронів, які спізнюються, передбачаються за допомогою шести постійних розпаду. Частку кожної групи нейтронів, які спізнюються, від ділення швидкими або тепловими нейтронами розраховано за допомогою спектрального коду HELIOS [9] для кожного типу TB3 залежно від глибини вигорання палива з урахуванням вагового внеску кожного з ізотопів та додано в розроблену раніше бібліотеку НФК [2].

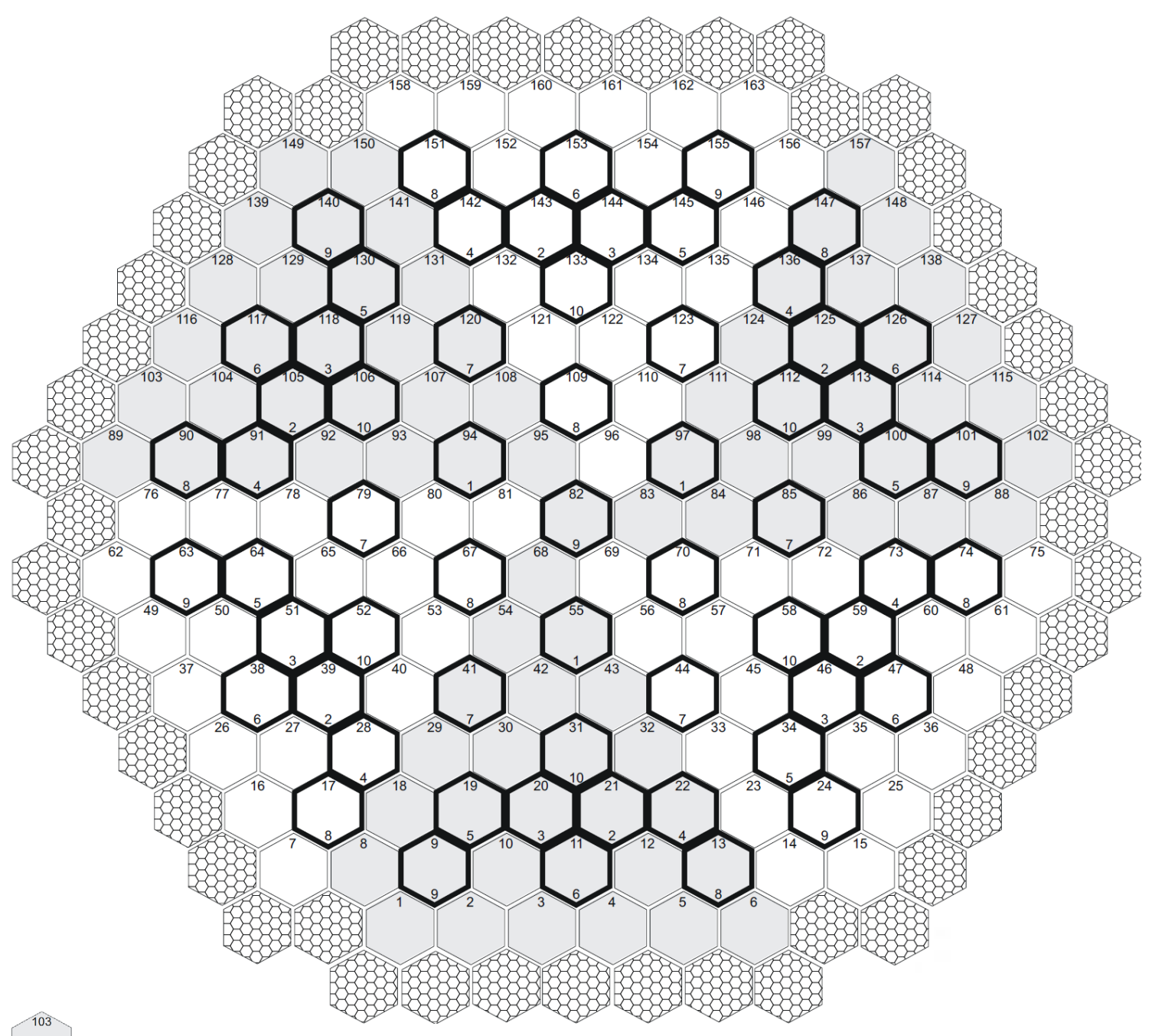

чарунка TB3

чарунка ТВЗ з ОР СУЗ

чарунка відбивача

Рисунок 1 - Модель Ак3 (360 симетрія) для коду PARCS 
Таблиця 1 - Теплогідравлічні характеристики моделі Ак3

\begin{tabular}{|l|c|c|}
\hline \multicolumn{1}{|c|}{ Назва } & Одиниці вимірювання & Значення \\
\hline Кількість твел у касеті & шт & 312 \\
\hline Довжина паливного стовпа в холодному стані & м & м,53 \\
\hline $\begin{array}{l}\text { Внутрішній діаметр оболонки твела (осьового отвору в } \\
\text { паливній таблетці) }\end{array}$ & мм (1,5) \\
\hline Зовнішній діаметр оболонки твела (паливної таблетки) & мм & $9,1(7,57)$ \\
\hline Середня потужність ТВ3 & Кг/с & 18,4 \\
\hline Середня витрата теплоносія через ТВз & Вт/(м²К) & 9000 \\
\hline $\begin{array}{l}\text { Середня теплопровідність газового зазору між } \\
\text { паливною таблеткою та оболонкою }\end{array}$ & & \\
\hline
\end{tabular}

\section{3 Теплогідравлічна модель Ак3, ТВ3 і тепловидільного елемента (твел)}

Під час розробки теплогідравлічної моделі BВEP-1000 для визначення гідравлічних характеристик АкЗ використано геометричні розміри Ак3, паливної касети і пучка твелів відповідно до конструкторської та експлуатаційної документації. Основні теплогідравлічні характеристики розробленої моделі АкЗ ВВЕР-1000 наведено в Таблиці 1.

У розробленій теплогідравлічній моделі Ак3 відповідно до кожної ТВЗ і чарунок, що імітують радіальний відбивач, ставився один теплогідравлічний канал. Геометрична модель паливного стрижня задана шістьма радіальними шарами в паливній таблетці. Кількість зон обрано на підставі досвіду виконаного аналізу впливу їх кількості на величину середньої температури палива по таблетці.

\section{4 Результати валідаційних розрахунків}

Валідаційні розрахунки виконані для МКР та номінального рівня потужності для чотирьох паливних завантажень енергоблока № 2 ВП ХАЕС. Вихідні параметри для розрахунків наведено в Таблиці 2.

Під час проведення валідаційних розрахунків НФХ АкЗ реактора визначено такі параметри: ефективність робочої групи ОР СУЗ; коефіцієнти реактивності; коефіцієнти нерівномірності енерговиділення касети $\left(\mathrm{k}_{\mathrm{q}}\right)$ та шару касети за висотою $\left(\mathrm{k}_{\mathrm{v}}\right)$; зміну концентрації борної кислоти впродовж кампанії реактора.

Для порівняння аксіального розподілу енерговиділення обрано три ТВ3, що перебувають у різних станах: ТВЗ із зануреним ОР СУЗ; ТВЗ із максимальним відхиленням енерговиділення; ТВЗ із максимальним навантаженням. Цей набір характерис-

Таблиця 2 - Вихідні параметри розрахунку для МКР та номінального рівнів потужності

\begin{tabular}{|l|c|c|}
\hline \multicolumn{1}{|c|}{ Назва } & \multicolumn{2}{c|}{ Потужність } \\
\cline { 2 - 3 } & МКР & Номінальна \\
\hline Теплова потужність реактора, МВт & 0,1 & 3000,0 \\
\hline Температура теплоносія на вході в реактор, ${ }^{\circ} \mathrm{C}$ & 279 & 287 \\
\hline Витрата теплоносія на входів в реактор, кг/с & 16870,0 & 16870,0 \\
\hline Тиск над Ак3, МПа & 15,7 & 15,7 \\
\hline Отруєння ксеноном, самарієм & 0 & стаціонарне \\
\hline
\end{tabular}


тик дозволяє виявити можливі помилки та зробити висновки про коректність розробленої моделі АкЗ BBEP-1000.

Результати розрахунків з використанням коду PARCS порівняно з даними експериментальних досліджень на МКР потужності для перших чотирьох паливних завантажень наведено в Таблиці 3.

Проведені розрахунки інтегральної та диференціальної ефективності робочої групи ОР СУЗ для першого паливного завантаження, результати яких наведено нижче (Рисунок 2). Аналогічні розрахунки проведені для другого, третього та четвертого паливних завантажень.

Результати розрахунків з використанням коду PARCS порівняно з даними експериментальних досліджень на номінальному рівні потужності наведено в Таблиці 4.

На Рисунку 3 зображено зміну концентрації борної кислоти впродовж кампанії реактора для різних паливних завантажень для розрахункових моделей кодів PARCS, DYN3D та даних експериментальних досліджень.

Основні результати порівняльного аналізу розрахункових даних, отриманих з використанням коду PARCS, з результатами експериментальних досліджень наведено в Таблиці 5.
Для підтвердження застосовності розробленої моделі для моделювання перехідних та аварійних режимів було також проведено розрахунок перехідного процесу, пов язаного зі спрацьовуванням ПРБ та подальшим спрацьовуванням АЗ унаслідок досягнення уставки за періодом збільшення потужності реактора, що мав місце під час роботи третього паливного завантаження енергоблока № 2 ВП ХАЕС [10].

На Рисунку 4 зображено залежність зміни нейтронної потужності реактора від часу у разі спрацьовування ПРБ, отриману за допомогою розрахунку кодом PARCS 3 моделюванням подальшого спрацьовування Ак3. На Рисунку 4 також наведено результати показань каналів вимірюваннянейтронноїпотужності(УНО-1-УНО-6) та результати розрахункового моделювання програмою DYN3D, отримані в рамках роботи [10]. ЯквиднозРисунка 4, змінипотужності, розрахункові параметри під час перехідного процесу досить добре корелюють як 3 експериментальними даними, так і з результатами за програмою DYN3D. Водночас зауважимо, що точність моделювання обмежена грубою дискретизацією показань датчиків АКНП (1,0 сек).

Таблиця 3 - Результати розрахунків на МKР потужності з використанням коду PARCS порівняно із даними експериментальних досліджень

\begin{tabular}{|c|c|c|c|c|c|c|c|c|}
\hline \multirow{3}{*}{$\begin{array}{c}\text { Результати } \\
\text { розрахунків }\end{array}$} & \multicolumn{8}{|c|}{ Паливне завантаження } \\
\hline & \multicolumn{4}{|c|}{1} & \multicolumn{4}{|c|}{2} \\
\hline & \multicolumn{2}{|c|}{$\mathrm{P}$} & \multicolumn{2}{|c|}{$E$} & \multicolumn{2}{|c|}{$P$} & \multicolumn{2}{|c|}{$E$} \\
\hline $\mathrm{D}$ & \multicolumn{2}{|c|}{5,23} & \multicolumn{2}{|c|}{5,92} & \multicolumn{2}{|c|}{6,30} & \multicolumn{2}{|c|}{6,01} \\
\hline \multirow[t]{2}{*}{$\mathrm{D}$} & \multicolumn{2}{|c|}{7,89} & \multicolumn{2}{|c|}{7,23} & \multicolumn{2}{|c|}{8,11} & \multicolumn{2}{|c|}{7,28} \\
\hline & * & $* *$ & * & ** & $* * *$ & * & $* * *$ & * \\
\hline \multirow[t]{3}{*}{$a_{t^{\prime}} 10^{-3} \% /\left({ }^{\circ} \mathrm{C}\right)$} & $-10,15$ & $-18,3$ & $-6,93$ & $-16,03$ & $-13,6$ & $-10,1$ & $-10,5$ & $-4,3$ \\
\hline & \multicolumn{4}{|c|}{3} & \multicolumn{4}{|c|}{4} \\
\hline & \multicolumn{2}{|c|}{$\mathrm{P}$} & \multicolumn{2}{|c|}{$E$} & \multicolumn{2}{|c|}{$P$} & \multicolumn{2}{|c|}{$E$} \\
\hline$\varepsilon, \%$ & \multicolumn{2}{|c|}{7,33} & \multicolumn{2}{|c|}{6,93} & \multicolumn{2}{|c|}{6,27} & \multicolumn{2}{|c|}{4,84} \\
\hline \multirow[t]{2}{*}{$\varepsilon_{,}^{\prime} \%$} & \multicolumn{2}{|c|}{8,81} & \multicolumn{2}{|c|}{8,57} & \multicolumn{2}{|c|}{7,79} & \multicolumn{2}{|c|}{6,26} \\
\hline & $* * *$ & * & $* * *$ & * & $* * *$ & * & $* * *$ & * \\
\hline$a_{t^{\prime}} 10^{-3} \% /\left({ }^{\circ} \mathrm{C}\right)$ & $-16,6$ & $-13,6$ & $-11,6$ & $-9,3$ & $-18,3$ & $-15,0$ & $-15,4$ & $-12,0$ \\
\hline
\end{tabular}

Примітка: P - PARCS; E - Експеримент; $\mathrm{H}_{10}$ - положення робочої групи № 10, см ( $^{*}-3 a \mathrm{H}_{10}=284 \mathrm{~cm}$; ** $-3 a \mathrm{H}_{10}=0 \mathrm{~cm}$; *** - за $\mathrm{H}_{10}=106,5 \mathrm{~cm}$.); $a_{\mathrm{t}}$ - температурний коефіцієнт реактивності, $10^{-3} \% /\left({ }^{\circ} \mathrm{C}\right) ; \Delta \rho$ - ефективність АЗ за умови одного застряглого ОР СУ3, \%; $\Delta \rho^{\prime}$ - повна ефективність АЗ, \%. 


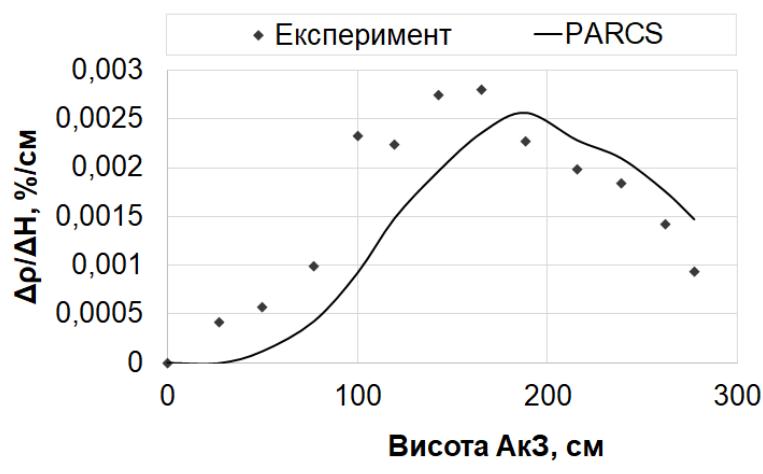

a)

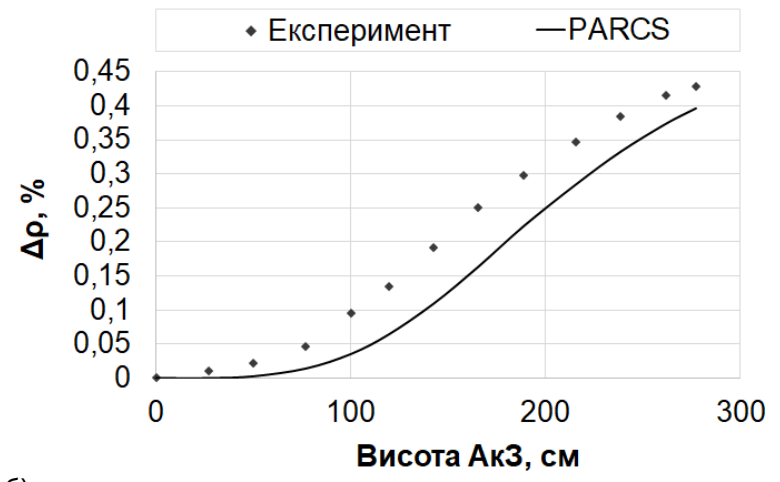

б)

Рисунок 2 - Результати розрахунків інтегральної та диференціальної ефективності робочої групи ОР СУЗ для першого паливного завантаження:

а) інтегральна ефективність робочої групи ОР СУЗ; б) диференціальна ефективність робочої групи ОР СУз

Таблиця 4 - Результати розрахунків з використанням коду PARCS порівняно з даними експериментальних досліджень на номінальному рівні потужності

\begin{tabular}{|c|c|c|c|c|c|c|}
\hline \multirow{2}{*}{ 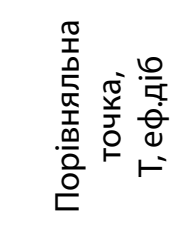 } & \multirow{2}{*}{ 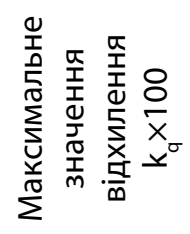 } & \multirow{2}{*}{ 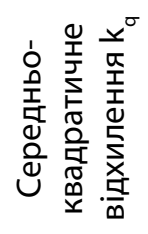 } & \multirow{2}{*}{ 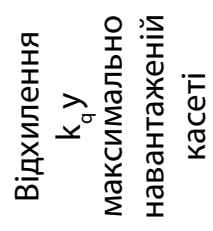 } & \multirow{2}{*}{ 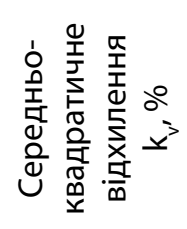 } & \multicolumn{2}{|c|}{ Відхилення, \% } \\
\hline & & & & & $\min$ & $\max$ \\
\hline \multicolumn{7}{|c|}{ Перше паливне завантаження } \\
\hline $1: T=29,8$ & $-5,09$ & 0,022 & $-0,030$ & 8,29 & $-10,17$ & 10,09 \\
\hline $2: \mathrm{T}=90,8$ & 4,71 & 0,022 & $-0,030$ & 10,39 & $-11,19$ & 12,92 \\
\hline $3: T=148,2$ & 3,72 & 0,017 & $-0,023$ & 6,33 & $-8,52$ & 11,32 \\
\hline $4: T=208,7$ & 3,67 & 0,014 & $-0,012$ & 5,26 & $-7,49$ & 10,06 \\
\hline $5 T=264,2$ & 2,08 & 0,009 & $-0,013$ & 4,29 & $-6,61$ & 9,98 \\
\hline Загалом: & & & & 7,25 & 11,92 & 12,92 \\
\hline \multicolumn{7}{|c|}{ Друге паливне завантаження } \\
\hline $1: T=29,0$ & $-4,88$ & 0,016 & $-0,024$ & 4,58 & $-11,51$ & 6,44 \\
\hline $2: T=63,9$ & $-4,72$ & 0,016 & 0,015 & 3,40 & $-8,36$ & 5,65 \\
\hline $3: T=105,8$ & $-4,81$ & 0,014 & 0,020 & 3,74 & $-10,87$ & 5,15 \\
\hline $4: T=164,0$ & $-5,58$ & 0,015 & 0,020 & 3,83 & $-8,57$ & 9,00 \\
\hline $5: T=218,4$ & $-3,58$ & 0,012 & 0,014 & 3,68 & $-13,64$ & 7,79 \\
\hline Загалом: & & & & 3,87 & $-13,64$ & 7,79 \\
\hline \multicolumn{7}{|c|}{ Третє паливне завантаження } \\
\hline $1: T=90,1$ & 5,95 & 0,022 & $-0,024$ & 4,00 & $-5,46$ & 7,96 \\
\hline $2: T=128,8$ & 5,07 & 0,019 & $-0,024$ & 2,89 & $-5,54$ & 6,66 \\
\hline $3: T=168,8$ & 4,55 & 0,019 & 0,018 & 3,42 & $-5,92$ & 6,12 \\
\hline $4: T=219,8$ & 4,74 & 0,020 & $-0,001$ & 4,41 & $-6,18$ & 7,3 \\
\hline $5 \mathrm{~T}=268,9 ;$ & $-3,58$ & 0,013 & $-0,022$ & 4,69 & $-8,24$ & 10,89 \\
\hline Загалом: & & & & 3,94 & $-8,24$ & 10,89 \\
\hline \multicolumn{7}{|c|}{ Четверте паливне завантаження } \\
\hline $1: T=81,1$ & 9,21 & 0,035 & 0,084 & 7,83 & $-12,19$ & 14,14 \\
\hline $2: T=134,8$ & $-6,33$ & 0,027 & 0,042 & 4,77 & $-9,25$ & 7,56 \\
\hline $3: T=216,9$ & $-5,43$ & 0,018 & 0,019 & 3,24 & $-7,00$ & 9,93 \\
\hline Загалом: & & & & 5,61 & $-12,19$ & 14,14 \\
\hline
\end{tabular}



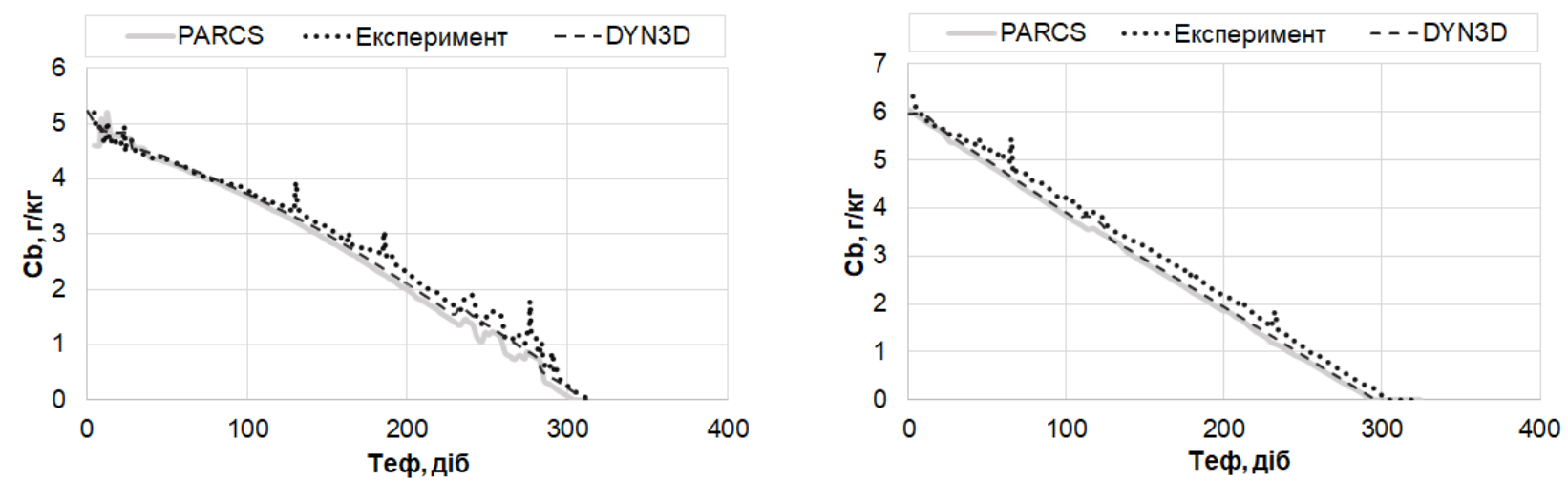

a)

б)
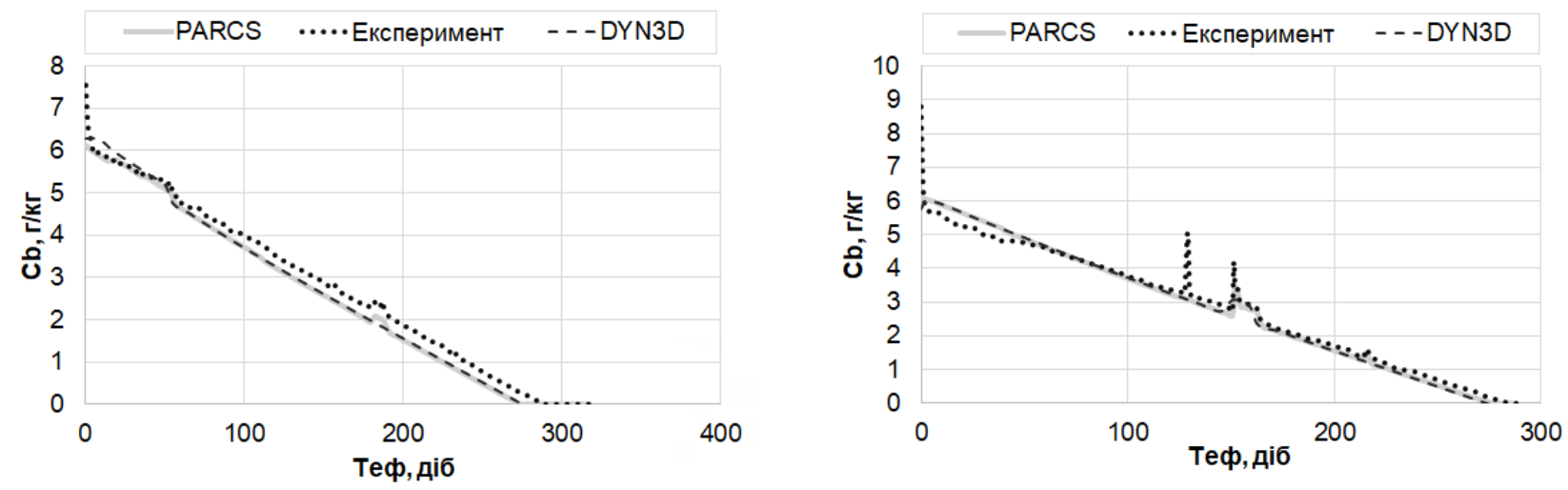

B)

Рисунок 3 - Зміна концентрації борної кислоти впродовж кампанії реактора для паливних завантажень: а) першого; б) другого; в) третього; г) четвертого

Таблиця 5 - Результати порівняльного аналізу розрахункових даних, отриманих з використанням коду PARCS, з результатами експерименту

\begin{tabular}{|l|c|c|}
\hline \multicolumn{1}{|c|}{ Характеристика } & Максимальні відхилення & $\begin{array}{c}\text { Середньоквадратичне } \\
\text { відхилення }\end{array}$ \\
\hline $\begin{array}{l}\text { Концентрація борної кислоти в теплоносії на } \\
\text { МКР, г/кг }\end{array}$ & $\pm 0,5$ & 1,67 \\
\hline $\begin{array}{l}\text { Концентрація борної кислоти в теплоносії на } \\
\text { номінальній потужності, г/кг }\end{array}$ & $\pm 0,3$ & 0,10 \\
\hline $\begin{array}{l}\text { Температурний коефіцієнт реактивності на } \\
\text { МКР, } 10^{-3} \% /\left({ }^{\circ} \mathrm{C}\right)\end{array}$ & $-5,8$ & - \\
\hline Ефективність робочої групи, \% & $-7,2$ & 2,4 \\
\hline Ефективність АЗ, \% & $-12 \ldots+30$ & 15,3 \\
\hline Потужність ТВ3 $\mathrm{k}_{\mathrm{q}^{\prime}}$ відн. од. $\times 100$ & $-7 \ldots+9$ & 1,97 \\
\hline $\begin{array}{l}\text { Потужність максимально навантаженої ТВ3 } \mathrm{k}_{\mathrm{q}^{\prime}} \\
\text { відн.од. } \times 100\end{array}$ & $-3 \ldots+8$ & 2,92 \\
\hline Потужність шару ТВ3 $\mathrm{k}_{\mathrm{v}^{\prime}} \%$ & $-14 \ldots+14$ & 5,32 \\
\hline
\end{tabular}




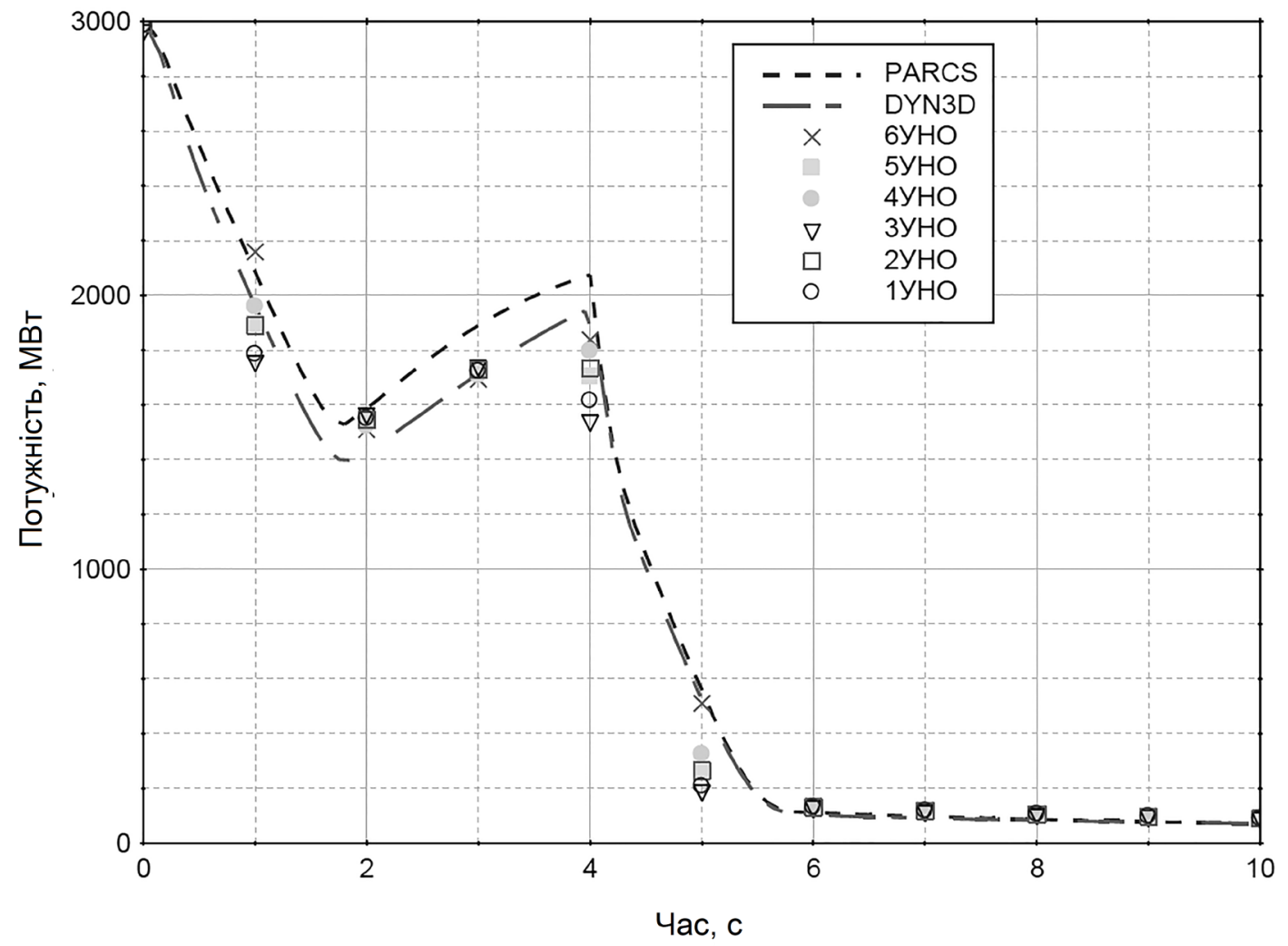

Рисунок 4 - Зміна потужності в ході перехідного процесу скидання групи ПРБ

\section{Висновки}

Наведено опис та результати всіх етапів розробки розрахункової моделі АкЗВВЕР-1000 для коду PARCS - підготовки бібліотеки НФК, розробки нейтронно-фізичної та теплогідравлічної складових моделі Ак3 та результати валідаційних розрахунків. Валідація розрахункової моделі ґрунтується на результатах порівняльного аналізу основних розрахункових НФХ із результатами, які отримані під час експериментальних досліджень чотирьох реальних паливних завантажень енергоблока № 2 ВП ХАЕС, а також з результатами розрахунку з використанням валідованого коду DYN3D для аналогічних розрахункових станів. Розрахункові моделювання охоплювали стани на МKР та номінальному рівні потужності, і за різних положень робочої групи ОР СУЗ, а також перехідний процес зі спрацюванням ПРБ для третього паливного завантаження енергоблока № 2 ВП ХАЕС.

Результати валідаційних розрахунків вказують на задовільну спроможність розробленої моделі разом із підготовленою бібліотекою НФК моделювати як стаціонарні стани Ак3 ВВЕР-1000, так і перехідні процеси, що супроводжуються просторовими деформаціями поля енерговиділення в Ак3 реактора. Розроблена та валідована модель Ак3 ВВЕР-100 для коду PARCS може бути використана для проведення розрахунків з метою підвищення якості виконання технічної оцінки обгрунтувань безпеки AEC, особливо у випадках моделювання перехідних процесів з використанням системного коду, пов'язаного з PARCS.

\section{Список використаної літератури}

1. Downar T., Xu Y., Seker V. «PARCSv3.0 Theory Manual». UM-NERS-09-001. October, 2009.

2. Завдання на роботу № 4 до угоди № 358160 між Брукхейвенською Національною Лабораторією та ДНТЦ ЯРБ від 28.03.2019 року.

3. Розробка та валідація моделі ВВЕР-1000 для коду PARCS. Підготовка бібліотеки НФК для ТВ3, що використовуються В бенчмарку. (Завдання № 27 до угоди № 257586 від 29.03.2016, етап 1, проміжний): звіт про НДР. ДНТЦ ЯРБ; керівник Ю. М. Овдієнко; виконавці: М. Л. Єременко, О. В. Кучин. К., 2017.

4. Lötsch T., Khalimonchuk V., Kuchin A. Proposal of a benchmark for core burnup calculations for a WWER-1000 reactor core. Proceedings of the 19th AER Symposium on 
WWER Reactor Physics and Reactor Safety, St. Constantine and Elena resort, Bulgaria, Sept. 21 - 25, 2009, P. 53 - 108.

5. Ovdiienko I., leremenko M., Khalimonchuk V., Kuchin A. Evolution of SSTC WWER cross section library for DYN3D code. Proceedings of the twenty-second Symposium of AER on VVER Reactor Physics and Reactor Safety. Průhonice, Czech Republic, 1-5 October, 2012. P. 83 - 91.

6. Овдієнко Ю.М., Кучин О.В., Єременко М.Л., Власенко П. А. Адаптація розрахункових моделей HELIOS паливних касет ВBEP-440 для використання програмою TRACE/PARCS. Ядерна та радіачійна безпека. 2019. № 1(81), C. 46-51. doi: 10.32918/nrs.2019.1(81).08.

7. У 0401.21.00.000 ДКО. Комплекс составных частей активной зоны ВВЭР-1000 (тип В-320. В-338): Каталожное описание.

8. Хетрик Д. Динамика ядерных реакторов. Пер. с англ. М.: Атомиздат, $1975.400 \mathrm{c}$.

9. HELIOS: Documentation. Studsvik Scandpower, 2007.

10. Овдиенко Ю. Н., Кучин А.В., Халимончук В.А. О срабатывании аварийной защиты по периоду реактора в режиме ускоренной разгрузки блока с ВВЭР- 1000. Ядерна та радіаційна безпека. 2008. Том. 11, Вип. 4. С. 15 - 24.

\section{References}

1. Downar, T., Xu, Y., Seker, V. (2009). PARCSv3.0 theory manual. UM-NERS-09-001.

2. Task Order No.4, BOA No. 358160 between BNL and SSTC NRS dated 28 March 2019.

3. Development and validation of VVER-1000 model for PARCS code. Preparation of the library of neutronic constants for FAs used in the benchmark. (Task No. 27, BOA No. 257586 dated 29 March 2016, Stage No. 2). SSTC NRS, Kyiv, 2017, 28 p.

4. Lötsch, T., Khalimonchuk, V., Kuchin, A. (21-25 September 2009). Proposal of a benchmark for core burnup calculations for a WWER-1000 reactor core. Proceedings of the $19^{\text {th }}$ AER symposium on WWER reactor physics and reactor safety. St. Constantine and Elena resort, Bulgaria, $53-108$.

5. Ovdiienko, I., leremenko, M., Khalimonchuk, V., A. Kuchin. (1-5 October 2012). Evolution of SSTC WWER cross section library for DYN3D code. Proceedings of the twenty-second symposium of AER. Pruhonice, Czech Republic, 83 - 91.

6. Ovdiienko, I., Kuchyn, O., leremenko, M., Vlasenko, P. (2019). Adaptation of HELIOS models for WWER-440 fuel assemblies to application by the TRACE/PARCS program nuclear and radiation safety. 1 (81), $46-51$.

7. $U$ 0401.21.00.000 DKO. Complex components of the WWER-1000 fuel core (type V-320, 338), Catalog descriptions.

8. Hetrick, David L. (1975). Dynamics of nuclear reactors. Atomizdat, Moscow, $400 \mathrm{p}$.

9. HELIOS: Documentation. Studsvik Scandpower, 2007.

10. Ovdiienko, Y., Kuchin, A., Khalimonchuk, V. (2008). Analysis of the scram actuation by period during WWER-1000 fast unloading. Nuclear and Radiation Safety, SSTC NRS, 4 (2), $3-11$.

\section{Development and Validation of WWER-1000 Model for the PARCS Code}

\section{Kukhotska O., Ovdiienko I., leremenko M.}

State enterprise «State Scientific and Technical Center for Nuclear and Radiation safety», Kyiv, Ukraine

Modern approaches to the modeling of processes in the reactor core (RC), primarily in transient and emergency modes, in order to safety analyze of nuclear reactors, require using combined thermohydraulic and neutronic computer programs. Computer code TRACE is one of such programs with the module of three-dimensional PARCS kinetics.

Development of a computer model of the water-cooled water-moderated reactor (WWER-1000) for the PARCS code and its subsequent validation is a complex multistage task starting with the preparation of the library of neutronic constants, whose quality affects the accuracy of modeling physical processes in $\mathrm{RC}$, and ending with validation calculations and their analysis.

This article describes briefly all stages of developing a computer model and results of validation calculations: approaches to preparing the library of neutronic constants required for calculations by the PARCS code, describes briefly developed neutronic and thermohydraulic RC models and presents the results of validation calculations of the developed WWER-1000 model for the PARCS code.

The purpose of the performed calculations is to validate the developed computer model of WWER1000 core for the PARCS code, namely to confirm that this developed model is suitable for application in the framework of neutronic calculations for steady states and transient and emergency operation modes of WWER-1000.

Computer model validation consisted in a comparative analysis of the obtained calculation results of basic neutronic characteristics and the results obtained during experimental studies of four real fuel loadings for Khmelnitsky NPP Unit 2 and with the calculation results using the DYN3D code for similar calculation states.

The computer modeling covered states at hot zero power and full power, as well as in different positions of the control rod group and transient (dynamic) process on the actuation of accelerated unit unloading for KhNPP - Unit 2.

Keywords: model validation, few group constants, computer model, WWER, HELIOS, PARCS.

Отримано 31.03.2021 